\title{
Konsep Pemasaran Untuk Usaha Baru Hidroponik Titik Tanam Minimum
}

\author{
Ema Nurzainul Hakimah \\ Universitas Nusantara PGRI - Kediri \\ E-mail: emahakimah@unpkediri.ac.id
}

\begin{abstract}
This research activity is motivated by the lack of optimal marketing of hydroponic products produced by PKM partner, PKM Program of Kemenristek Dikti Grant 2017, Pokja 4 TPPKK and Menur Posyandu, Blabak Village, Pesantren District, Kediri City, East Java Province. The success of hydroponic cultivation has not been followed by the ability to market. The accuracy of the marketing concept is expected to be able to maximize profits, when pranoto mongso consept in the limited land, and the minimum planting point can be done by partners. Based on this background, the formulation of the problem in this study is "What is the marketing concept that is applied to new hydroponic businesses ?, which is done by partners, namely Working Group 4 TPPKK and Menur Posyandu Blabak Village, Kediri City Islamic Boarding School District. The purpose is to find out the right and effective marketing concept for the optimal sale of hydroponic products with limited planting point conditions. Using qualitative research methods with a phenomenological approach, it is expected that direct observation and in-depth interviews with partners as informants. The selected informants have met criteria $5 R$ (relevance, recommendation, rapport, readiness, and reassurance). From in-depth interviews and observations, the data is validated through tests of internal validity (credibility), external validity (transferability), reliability (dependability) and triangulation techniques. The phenomenological analysis technique applied in this research is trancendental phenomenology analysis. The results of the study show that there is an application of the marketing concept, which is then referred to as the concept of social and relational marketing, which emphasizes networking, personal selling and direct selling with marketing media in the form of social media such as Facebook, Whatsapp, Instagram.
\end{abstract}

Keywords: Social and Relational Marketing Concepts, Hydroponics

\begin{abstract}
ABSTRAK
Kegiatan penelitian ini dilatarbelakangi kurang optimalnya pemasaran produk hidroponik yang dihasilkan mitra program PKM Hibah Kemenristek Dikti Tahun 2017 yaitu Pokja 4 TPPKK dan Posyandu Menur Kelurahan Blabak Kecamatan Pesantren Kota Kediri Propinsi Jawa Timur. Keberhasilan budidaya tanaman hidroponik belum diikuti kemampuan memasarkan. Ketepatan konsep memasarkan diharapkan mampu memaksimalkan laba, ketika pranoto mongso pada lahan terbatas dengan titik tanam minimum dapat dilakukan oleh mitra. Berdasarkan latar belakang tersebut, maka rumusan masalah pada penelitian ini adalah "Bagaimana konsep pemasaran yang diterapkan pada usaha baru hidroponik?, yang dilakukan.oleh mitra yaitu Pokja 4 TPPKK dan Posyandu Menur Kelurahan Blabak Kecamatan Pesantren Kota Kediri. Adapun tujuannya adalah untuk mengetahui konsep pemasaran yang tepat dan efektif untuk
\end{abstract}


penjualan produk hidroponik yang optimal dengan kondisi titik tanam yang terbatas. Menggunakan metode penelitian kualitatif dengan pendekatan fenomenologi, diharapkan dengan pengamatan secara langsung dan wawancara mendalam kepada mitra sebagai informannya. Informan yang dipilih telah memenuhi kriteria $5 R$ (relevance, recomendatioan, rapport, readiness, dan reassurance). Dari wawancara mendalam dan pengamatan, data divalidasi melaui uji validitas internal (credibility), validitas eksternal (transferability), reliabilitas (dependability) dan confirmability dengan teknik triangulasi. Teknik analisis fenomenologi yang diterapkan dalam penelitian ini adalah analisis fenomenologi trancendental. Adapun hasil penelitian menunjukkan bahwa terdapat penerapan konsep pemasaran yang selanjutnya konsep pemasaran tersebut disebut sebagai konsep pemasaran sosial dan relasional, yang menekankan pada networking, personal selling dan direct selling dengan media pemasaran berupa media sosial seperti facebook, whats app, instagram.

\section{Kata kunci: Konsep Pemasaran Sosial dan Relasional, hidroponik}

\section{PENDAHULUAN}

Sejak tahun 2014, pasar sayuran hidroponik terus mengalami peningkatan permintaan, yaitu $10-20 \%$ per tahun khususnya oleh masyarakat yang tinggal di perkotaan (https://bisnisukm.com). Bukan hanya dikonsumsi oleh konsumen rumah tangga, namun demikian sudah merambah ke konsumen industry seperti supermarket, restoran, dan hotel. Bagi pengusaha hidroponik dengan lahan luas hal ini tentu merupakan kabar gembira, karena market share mereka sangat terbuka. Sebaliknya dengan petani hidroponik pemula dengan lahan terbatas dan skala usaha rumahan seperti mitra PKM kami yang hanya memiliki titik tanam sebanyak 728, modal dan pengetahuan pemasaran yang terbatas. Bagi pelaku hidroponik baru memulai usahanya memiliki tantangan yang berat untuk memasarkan produk yang dihasilkan, terlebih secara demografi konsumen berada di daerah sub urban. Masyarakat sub urban ini memiliki ciri perkotaan sekaligus pedesaan, sehingga karakteristik segmen ini sangat unik dilihat dari bergai unsur dalam segmentasi.

Setelah berhasil menciptakan produk yang memiliki keunggulan bersaing, masalah selanjutnya adalah bagaimana mereka dapat menyampaikan produk tersebut sampai ke tangan konsumen untuk dikonsumsi. Dalam bisnis hidroponik permasalahan yang sering dihadapi adalah menyampaikan nilai produk, bahwa sayuran hidroponik merupakan produk pangan yang memiliki berbagai keunggulan, sehingga meskipun terkategori dalam kelompok pangan tetapi memiliki peminat tersendiri. Dalam kegiatan pemasaran terdapat langkah awal yang wajib dilakukan oleh pemasar, yaitu melakukan 
segmentasi pasar. Salah satu unsur yang digunakan dalam segmentasi adalah demografi masyarakat (pendapatan, pekerjaan, pendidikan, tempat tinggal, dan jenis kelamin).

Sayuran merupakan bahan makanan yang termasuk dalam kebutuhan pokok dan utama bagi manusia. Pangan menurut teori Maslow adalah kebutuhan mendasar manusia, kali ini sedikit berbeda ketika jenis pangannya adalah sayuran yang belum lazim dikonsumsi dan termasuk dalam kategori sayuran mahal (hanya ada di supermarket dan hypermarket). Perkembangan demografi dan perilaku konsumen menjadikan kegitan pemenuhan permintaan akan sayuran ini menjadi sangat unik dan menarik untuk dipahami oleh para produsen sayuran khususnya pengusahan sayuran hidroponik. Pemenuhan sayuran bagi konsumen akan memiliki perspektif yang berbeda, dimana sebagian konsumen menganggap bahwa sayuran hidroponik adalah kebutuhan dan sebagian lagi menilai bahwa sayuran hidroponik tersebut adalah hanyalah sebuah keinginan semata. Sadar bahwa ini adalah produk pangan dengan spesifikasi khusus, belum menjadi produk pangan yang utama bagi masyarakat, masih rendahnya kesadaran masyarakat untuk hidup sehat, termasuk dalam convenience good dan terbatasnya faktor produksi (lahan), maka menjadi sangat menarik ketika pengusaha hidroponik ini mampu mencapai maksimalisasi penjualan dan mampu memasarkan produk sayuran hidroponiknya.

Fenomena terjadinya perubahan perilaku konsumen dalam mengkategorikan bahwa ini adalah kebutuhan dan keinginan, perlu ditanggapi dengan mengkaji faktor demografi dan phisikografi konsumen. Kegiatan mengidentifikasi segmen berdasarkan faktor demografi dan phisikograsi sekaligus menentukan pasar sasaran ini harus dilakukan oleh pengusaha hidroponik bahkan sebelum keputusan memulai usaha hidroponik ini diambil. Dengan demikian, setelah mampu menghasilkan sayuran hidroponik yang berkualitas, harapan untuk mendapatkan keuntungan maksimal melalui keberhasilan pemasaran dapat tercapai. Proses untuk menciptakan, mengkomunikasikan, dan menyerahkan nilai kepada pelanggan dan mengelola hubungan pelanggan dengan cara yang mengguntungkan bagi pengusaha, inilah yang dimaksud dengan pemasaran (Kotler, 2009:6).

Menurut Kotler dan Armstrong (2012:62), "promosi adalah suatu unsur yang digunakan untuk memberitahukan dan membujuk pasar tentang produk atau jasa yang baru pada perusahaan melalui iklan, penjualan pribadi, promosi penjualan, maupun 
publikasi". Kotler dan Armstrong (2012:408) mendefinisikan "bauran promosi (promotion mix) sebagai perpaduan spesifik alat-alat promosi yang digunakan perusahaan untuk mengkomunikasikan value ke customer secara persuasif dan membangun customer relationships". Bauran promosi yang meliputi iklan, personal selling, promosi penjualan, public relations, dan penjualan langsung, dalam perkembangannya melimiki strategi khusus dalam pengaplikasiannya. Hal ini sekali lagi tidak dapat dipisahkan dari perubahan perilaku konsumen sesuai segmen produk dan juga perkembangan teknologi. Berdasarkan survei yang dilakukan oleh Asosiasi Penyelenggara Jasa Internet Indonesia pertumbuhan pengguna internet di Indonesia menempati urutan ke -6 dunia dengan 102 juta pengguna internet. Banyak faktor yang mempengaruhi perkembangan internet saat ini diantaranya infrastruktur teknologi informasi yang menyediakan akses internet yang menyeluruh dan cepat. Penetrasi dan efek internet tidak hanya memudahkan, memanjakan orang dalam berkomunikasi dan berinteraksi, namun sekaligus turut menyuburkan usaha-usaha baru dengan pasarnya masing-masing (Hasanudin dkk, 2011:308).

\section{Fokus Penelitian}

Yang menjadi fokus dalam penelitian ini adalah "Bagaimana konsep pemasaran yang diterapkan pada usaha baru hidroponik?”, yang dilakukan.oleh mitra yaitu Pokja 4 TPPKK dan Posyandu Menur Kelurahan Blabak Kecamatan Pesantren Kota Kediri Provinsi Jawa Timur.

\section{Tujuan Penelitian}

Adapun tujuannya adalah untuk mengetahui konsep pemasaran dan bauran promosi yang tepat dan efektif untuk penjualan produk hidroponik yang optimal dengan kondisi titik tanam (lahan) yang terbatas.

\section{TINJAUAN PUSTAKA}

\section{Konsep Pemasaran Sosial dan Relasional}

Dalam melaksanakan kegiatan pemasaran ini, pengusaha kurang bijak jika hanya memperhatikan pada kebutuhan penjualan atau optimalisasi keuntungan. Perkembangan konsep pemasaran yang tidak lepas dari perkembangan peradapan manusia, dimulai sejak era rovolusi industri yaitu dengan ditemukannya mesin uap dan berkembangnya mesin produksi sehingga terjadi peralihan dalam mendefinisikan 
kebutuhan dan keinginan konsumen. Pada masa sebelum revolusi industri, produsen hanya fokus pada produksi maka setelah revolusi industri produsen merubah fokusnya menjadi berorientasi pada produk, yaitu dengan menciptakan produk yang berkualitas, mempunyai daya saing harga yang baik melului penekanan biaya produksi. Sejarah pemasaran yang berkembang pada tahun 1990 an adalah pemasaran relasi (relational marketing concept) dan pemasaran yang bertanggungjawab sosial.

Pemasaran relasi mempunyai tujuan pada pengembangan hubungan agar bertahan lama dan mendalam dengan semua orang atau organisasi yang secara langsung maupun tidak langsung mempengaruhi keberhasilan kegiatan pemasaran perusahaan. Dalam konsep pemasaran ini terdapat dua kegiatan utama yaitu aktifitas menjaga hubungan dengan pelanggan (Customer Relationship Manajemen - CRM) dan aktifitas menjaga hubungan dengan mitra (Partner Relationship Manajemen - PRM) (Kotler dan Keller, 2009:171). Adapun pemasaran bertanggung jawab sosial adalah pemasaran yang menitik beratkan pada bagaimana menciptakan kesejahteraan pada masyarakat dengan mengedepankan etika bisnis, lingkungan, hukun dan juga masyarakat. Pada masa ini perusahaan-perusahaan yang sudah berbetuk Tbk mulai gencar sadar akan kepedulian lingkungan dengan melakukan manajemen limbah yang baik, menggunakan sebagai dana perusahaan untuk kegiatan CSR (Coorporate Social Responsibility), dan hal ini juga dimasukkan sebagai materi iklan. Di era digital ini disebut masa modernisasi elektronik yang dimulai dari tahun 2000 ke atas, yang mana ditandai dengan berubahnya cara berhubungan antara pelanggan dengan perusahaan. Penggunaan internet dan media sosial merupakan alat yang sangat efektif dalam melakukan kegitan pemasaran.

Lee Odden - Chief Executive Officier, TopRank Online Marketing dalam Malau (2017:26), menyatakan definisi modern marketing adalah praktik menciptakan nilai untuk saling menguntungkan memenuhi kebutuhan konsumen dengan tujuan bisnis. Dalam aksinya, yang berarti mengetahui dan memenuhi perilaku khalayak sasaran/ masyarakat penemuan informasi, konsumsi dan berbagi dengan komunikasi yang relevan dan tepat waktu di seluruh siklus hidup pelanggan.

\section{Bauran Promosi}

Tugas yang paling sulit perusahaan adalah untuk mementukan kombinasi dari beberapa alat promosi sehingga dapat berhasil secara efektif, dengan demikian dana 
yang tersedia tidak terbuang dengan percuma. Bauran promosi yang umum dilaksanakan oleh perusahaan adalah iklan, promosi penjualan, hubungan masyarakat, penjualan personal dan pemasaran langsung.

Masing-masing bauran promosi tersebut di atas dapat diterapkan dengan memanfaatkan berbagai media. Pengusaha hidroponik menggunakan iklan, promosi penjualan, personal selling, dan sosial media dengan media yang disesuaikan dengan perilaku konsumen dan faktor-faktor yang mempengaruhi penjualan, diantaranya: kondisi dan kemampuan penjual (harga, jenis produk, syarat penjualan), kondisi pasar (jenis pasar, segmen, frekuensi pembeliannya, keinginan, kebutuhan), modal, kondisi organisasi perusahaan, dan faktor-faktor lain insidentil lain.

Pemasaran menggunakan sosial media dan internet (online) sangat dipilih oleh pengusaha baru khususnya pengusaha hidroponik yang memiliki titik tanam minimum atau lahan sempit. Hal ini didasarkan pada fakta bahwa pengguna sosial media di Indonesia lebih dari 132 juta dan terus akan meningkat, media internet sangat dekat dengan masyarakat sehingga menjadi ajang promosi yang mudah, murah, efektif. Media internet mampu mempercepat penyebarluasan informasi. Ada sejumlah alasan dari pengusaha terutama pengusaha baru mulai membidik pasar melalui internet, diantaranya: 1) saat ini penonton televise telah berpindah ke internet, 2) pasar internet menggunakan iklan yang selalu dapat bisa di up date setiap waktu sesuai keinginan dan kebutuhan pemasar dengan menggunakan biaya yang minimum, 3) jangkauan pasar internet sangatlah luas sehingga mampu menjangkau pembeli potensial dalam jumlah yang sangat besar dalam hitungan global, 4) biaya iklan online lebih murah dan bisa menggunakan konvergensi teks, audio, grafik, dan animasi sehingga lebih efisien untuk promosi persuasive, 5) internet sedang berkembang pesat secara interaktif dan mampu membidik kelompok tertentu dan atau perorangan. Saat ini target pasar yang dibidik yakni pengguna internet, sehingga perusahaan harus memfokuskan diri untuk melakukan promosi melalui internet (Salim, 2010:183).

Beberapa media sosial yang digunakan oleh pengusaha hidroponik ini, yaitu facebook, instagram (hidroponikhae), dan whatsapp group. Dalam praktik promosi penjualan, pemasar juga memberikan fee marketing/ bonus kepada konsumen yang berhasil mengajak konsumen lain melakukan pembelian. Dengan demikian dapat 
disepakati diawal bahwa kegiatan promosi sangat dimungkinkan akan melawati berbagai media sesuai dengan faktor-faktor yang mempengaruhi penjualan.

\section{METODOLOGI PENELITIAN}

\section{Pendekatan Penelitian}

Untuk dapat memahami fenomena yang dialami oleh subyek penelitian yaitu perilaku, persepsi, motivasi dan tindakannya dalam berinteraksi saat melakukan kegiatan pemasaran sayuran hidroponik, maka penelitian ini menggunakan pendekatan kualitatif. Hal ini dikarenakan data yang dipergunakan adalah berbentuk hasil wawancara, dokumentasi, dan catatan pribadi. Jenis penelitian yang digunakan adalah fenomenologi, dimana pengalaman subyektif atau suatu studi hasil tentang kesadaran dari prespektiif pokok seseorang (Moleong, 2017:14). Istilah fenomenologi sendiri sering dipergunakan untuk menunjukkan anggapan umum tentang pengalaman subyektif dari berbagai jenis dan tipe subyek yang telah ditemui.

\section{Ruang Lingkup}

Berdasarkan rumusan masalah dalam penelitian ini yaitu "Bagaimana konsep pemasaran yang diterapkan pada usaha baru hidroponik?, maka ruang lingkup penelitian ini berfokus pada konsep pemasaran yang dilakukan oleh pengusaha sayuran hidroponik yang memiliki lahan sempit di Kelurahan Blabak Kecamatan Pesantren Kota Kediri Propinsi Jawa Timur. Adapun informan yang akan dilibatkan dalam penelitian ini harus memenuhi kriteria Relevance (informan mempunyai keterkaitan dengan masalah yang diteliti), Recommendation (informan direkomendasikan oleh orang-orang yang terpercaya), Rapport (informan harus mampu melaporkan informasi dengan mendalam karena yang bersangkutan harus bisa dekat dengan peneliti), Readiness (informan harus bener-bener siap untuk diwawancarai), dan Reassurance (informan dijamin berbicara sesuai kebenaran), kelima kriteria informan ini sering disebut juga dengan 5R (Kamayanti, 2015).

\section{Jenis dan Sumber Data}

Penelitian ini menggunakan dua jenis data yaitu data primer berupa hasil wawancara langsung dengan para pemasar sayuran hidroponik (anggota Pokja 4 TPPKK dan Posyandu Menur 8 yang memenuhi syarat sebagai informan). Jenis data 
kedua adalah data sekunder yaitu berupa foto hasil dokumentasi selama penelitian dan berinteraksi bersama mitra dilapangan saat proses penelitan.

\section{Prosedur Pengumpulan Data}

Proses pengumpulan data pada penelitian ini menggunakan beberapa teknik diantaranya :

\section{Observasi}

Dalam observasi ini peneliti melakukan pengamatan yang sistematis terhadap gejala - gejala yang diteliti. Peneliti melakukan observasi awal dengan cara berkumpul dengan beberapa anggota Pojka 4 TPPKK dan anggota Posyandu Menur 8 yang dinilai peneliti sering melakukan kegiatan pemasaran sayuran hidroponik hasil usaha mereka.

2. Wawancara mendalam

Wawancara yang dilakukan peneliti dalam penelitian ini merupakan alat rechecking atau pembuktian terhadap informasi atau keterangan yang diperoleh sebelumnya. Wawancara ini dilakukan dengan tujuan untuk memperoleh keterangan dengan tanya - jawab sambil bertatap muka antara pewawancara dengan informan dengan atau tanpa pedoman wawancara, yang mana dalam hal ini pewawancara dan informan dapat terlibat dalam kehidupan sosial yang relatif lama.

3. Dokumentasi

Dalam kegiatan penelitian ini, peneliti mengambil data berupa catatan, foto, mengikuti story status whatsapp, instragram dan juga facebook informan, terkait pengaplikasian konsep pemasaran dan bauran promosi diterapkan baik secara offline maupun online.

\section{Pengecekan keabsahan temuan}

Pengecean keabsahan data dalam penelitian ini menggunkan teknik triangulasi yaitu menghilangkan perbedaan konstruksi kenyataan yang terdapat dalam konteks suatu studi sewaktu mengumpulkan data tentang kejadian-kejadian dan hubungan dari berbagai pandangan (Sugiono, 2018:274). Dalam hal ini pandangan-pandangan tentang konsep pemasaran dan bauran promosi pemasaran hidroponik yang diperoleh dari informan dipilah-pilah mana pandangan yang sama dan mana pandangan yang berbeda antara beberapa informan sebagai sumber data. 


\section{Teknik Analisis Data}

Pada penelitian ini analisis data yang digunakan yaitu berdasarkan pada analisis fenomenologi transendental. Fenomenologi transendental lebih berfokus pada studi kesadaran. Pernyataan Husserl dalam Kamayanti (2016:151), "aku dalam fenomenologi merupakan pusat dari lingkungan, akhirnya mengarah pada bagaimana aku dalam tubuhku yang mengambil ruang dan tempat tertentu untuk memperoleh pengalaman. Pengalaman ini nantinya akan membentuk intuisi dari aku". Dalam teknik analisis fenomenologi transendental terdapat beberapa kata kunci yang perlu dipahami yaitu:

a) Noema

Analisis fenomenologi selalu diawali dengan melakukan identifikasi noema yang merupakan proses analisis bagian terluar dari temuan.

b) Epoche (Bracketing)

Setelah melakukan identifikasi noema tahap selanjutnya ialah epoche yang merupakan proses pengelupasan dari yang terluar sampai dengan yang terdalam.

c) Noesis

Tahapan selanjutnya setelah epoche yaitu noesis atau pemaknaan yang lebih mendalam. "Noesis" merupakan "kesadaran yang muncul akibat pengalaman karena dan pada waktu dan tempat tertentu" (Kamayanti, 2016:154).

d) Intentional Analysis

Setelah mengetahui noema dan noesis, diperlukan pemahaman lanjutan untuk mengetahui bagaimana noema bisa membentuk noesis. Pemahanan ini disebut juga intentional analysis.

e) Eidetic Reduction

Tahap terakhir yaitu menentukan hasil dari pemaknaan-pemaknaan yang telah dilakukan atau biasa disebut dengan eidetic reduction.

\section{HASIL \& PEMBAHASAN}

\section{Karakteristik informan}

Informan pertama, pada penelitian ini yang menjadi informan pertama adalah Ibu Budi yang sekaligus ketua Pokja 4 TPPKK kelurahan Blabak kecamatan Pesantren kota Kediri. Sebagai mitra hibah PKM peneliti, Ibu Budi ini adalah yang paling mengetahui 
pranoto mongso tanaman budidaya hidroponik yang diproduksi dan sangat terlibat dalam proses pemasarannya.

Informan kedua adalah Ibu Restin, selain sebagai warga perumahan Villa Bulurejo yang berprofesi sebagai ibu rumah tangga dan dosen, yang bersangkutan adalah anggota tim hibah PKM yang juga mendampingi mitra mulai proses budidaya sampai dengan pemasarannya. Beberapa kunjungan dan permintaan sayuran hidroponik dari instansi dan masyarakat hasil dari kebun hidroponik merupakan hasil dari kegiatan pemasaran dan promosi yang dilakukan melalui sosial medianya (instagram, facebook, dan whatsapp).

Informan ketiga adalah Ibu Tyas, ketua Posyandu Menur 8 kelurahan Blabak kecamatan Pesantren kota Kediri, yang sangat terlibat dalam pengelolaan produk sayuran hidroponik, diantaranya untuk memenuhi kebutuhan sayuran balita untuk program PMBA (pemberian makan untuk bayi dan anak). Berprofesi sebagai ibu rumah tangga dengan pendidikan terakhir SMA, mitra hibah ini mampu mengkomunikasikan produk hidroponik ini kepada siapapun yang ditemuinya, dan sekaligus memamerkan di sosial medianya (facebook dan whatsapp). Hal ini terbukti dalam setiap panen, permintaan sayuran darinya termasuk yang paling banyak (rata-rata lebih dari $2 \mathrm{~kg}$ setiap panennya).

\section{Hasil analisis data}

\section{Identifikasi Noema}

Pada identifikasi noema, peneliti mencoba menggali informasi mengenai konsep pemasaran dan bauran promosi yang diterapkan oleh warga mitra hibah PKM memasarkan hasil produksi kebun hidroponiknya. Informasi-informasi awal yang telah diperoleh berkaitan dengan unit analisis pertanyaan pada bab sebelumnya yaitu sebagai berikut:

a) Konsep pemasaran

Hasil identifikasi noema pada unit analisis konsep pemasaran diperoleh penjelasan sebagai berikut ini :

$\mathrm{R}$ (Interviewer) : "Apa tujuan akhir yang Bu Budi harapkan dari pemasaran sayuran hidroponik ini"

M (Informan 1): "harapannya sayuran yang kami hasilkan bersama warga ini dapat dimanfaatkan untuk mencukupi kebutuhan sayuran sehat di posyandu, warga masyarakat semakin sadar dengan pentingnya 
sayuran sehat dan yang pasti setiap panen sayurannya ludes terjual"

Identifikasi awal juga peneliti dapatkan dari pernyataan Ibu Restin berdasarkan kutipan wawancara berikut :

$\mathrm{R}$ (Interviewer) : "Ibu kan cerita bahwa warga harus mampu mandiri menghasilkan dan juga menjual hasil hidroponiknya, menurut pengalaman dan pendapat ibu, konsep pemasaran yang pas untuk usaha ini"

A (Informan 2) : "yang penting kita memberikan edukasi dulu tentang produk hidroponik ini, kan tidak semua orang paham manfaat dan kelebihan sayuran hidroponik. Kalo' sudah paham barulah kita ajak untuk menjadi pelanggan yang loyal sehingga bisa mengajak orang lain untuk mengkonsumsi sekaligus menjadi pelanggan juga"

Jawaban yang hampir sama dengan Ibu Budi dan Ibu Restin juga telah dipaparkan oleh Ibu Tyas sebagai berikut ini :

$\mathrm{R}$ (Interviewer) : "Nyuwun sewu buk, menurut panjenengan, bagaimana cara yang tepat untuk pemasaran hasil hidroponik kita?

$\mathrm{U}$ (Informan 3) : "Вu ema pun sungkan-sungkan tho, mosok aku dibasani... santai ae lho bu. Menurut kulo, sing penting masyarakat itu paham dulu apa itu sayuran hidroponik, kan kita jualnya lebih mahal dari sayuran umumnya. Jadi di warga Kelurahan Blabak ini khususnya harus ada sosialisasi dari kelurahan juga melalui pokja 4 PKK, sehingga setelah dapat wawasan terus kita ajak bareng-bareng mengkonsumsi dan memasarkan"

b) Bauran promosi

Hasil informasi awal mengenai bauran promosi sebagai berikut:

$\mathrm{R}$ (Interviewer) : "Untuk memasarkan hidroponik ini, Ibu promosinya bagaimana?"

M (Informan 1): "saya pake internet, foto-foto saya masukkan facebook, wa biar bisa diliat banyak orang teruma bolo-bolo saya. Saya juga membuatkan instagram khusus untuk hidroponik HA'E sesuai saran dosen-dosen UNP. Efeknya sekarang, setiap kali rapat di desa atau di kecamatan, wis dimanapun pokok e, mesti ditanya tentang hidroponik, buk. Bangga pokok e, gara-gara hibah PKM dari UNP ini pak Camat dan bu Camat sering ke perumahan sini.

Peneliti mendapat pernyataan Ibu Restin tentang promosi berdasarkan kutipan wawancara berikut :

$\mathrm{R}$ (Interviewer) : " media promosi apa yang tepat untuk usaha baru dan berskala kecil, untuk hidroponik hasil hibah PKM ini"

A (Informan 2) : "iklan dan promosi penjualan melalui internet. Beberapa kali saya coba melibatkan warga untuk menjadi agen penjualan dengan maksud awal ada yang fokus mengurus penjualan sayuruan, dan ternyata berhasil. Apalagi setelah tak kasih bonus karena menurut saya sudah melebihi target, lha sampek menolak pesanan lho!, 
sekarang tambah lebih rajin up load foto di status wa e, di facebooknya. Jadi menurutku promosi penjualan dan fee marketing sangat efektif"

Jawaban yang hampir sama dengan Ibu Restin juga dipaparkan oleh Ibu Tyas sebagai berikut ini :

$\mathrm{R}$ (Interviewer) : "Ibu Tyas membantu bu Budi menjual hasil hidroponik dengan cara apa?

$\mathrm{U}$ (Informan 3) : "selain saya woro-woro ke ibu-ibu pas di warung saat belanja, saya menggunakan internet bu kan gampang dan mesti diliat banyak orang". Bergabung dengan komunitas hidroponik Kediri sangat menguntungkan dari sisi keilmuan dan pemasaran, karena

\section{1) Epoche} kami terbantu saat terjadi penumpukan hasil panen

Proses epoche (pengelupasan terhadap informasi awal), pada unit analisis konsep pemasaran dan bauran promosi ini dilakukan peneliti dengan mengajukan pertanyaan terkait dengan informasi-informasi awal yang telah peneliti peroleh sebelumnya.

a) Konsep pemasaran

Hasil identifikasi epoche pada unit analisis konsep pemasaran diperoleh penjelasan sebagai berikut ini :

$\mathrm{R}$ (Interviewer) : "Jika sudah mendapatkan pembeli apakah ada harapan lainnya"

M (Informan 1): "ya pasti ada, saya berharap semua menjadi pelanggan setia. Jadi saat seminggu sebelum panen sudah habis ter-order"

Pernyataan lanjut yang diberikan Ibu Restin tentang konsep pemasaran berikut :

$\mathrm{R}$ (Interviewer) : " menurut ibu tujuan akhir dari konsep pemasaran yang akan ibu kembangkan itu seperti apa"

A (Informan 2): "konsep yang mengutamakan kualitas produk, kepuasan konsumen dan mempunyai pelanggan yang loyal". Saling membantu dengan pelaku usaha lain juga menjadi bagian penting untuk menjamin kelangsungan hidup usaha kami. Karena usaha kami ini termasuk rawan mati suri, mengingat lahannya sangat minim dan titik tanam yang sangat sedikit dibawah seribu titik.

Jawaban yang hampir sama dengan Ibu Budi dan Ibu Restin juga telah dipaparkan oleh Ibu Tyas sebagai berikut ini :

$\mathrm{R}$ (Interviewer) : “lebih lanjut apa yang ibu harapkan kedepan dari pemasaran hidroponik ini?

$\mathrm{U}$ (Informan 3) : "Saya berharap penjualan dari pelanggan ini dapat mengajak konsumen-konsumen lainnya. Dan mungkin bisa kami tingkatkan dengan menjalin hubungan yang baik sehingga kami punya jaringan pemasaran yang luas ". Saya rasa bergabung dengan komunitas sangat membantu dalam memasarkan hasil panen, 
karena uangnya bisa kontan lunas. Jadi kami langsung bisa mendapatkan modal usaha dan keuntungan lebih cepat.

b) Bauran promosi

Hasil wawancara kedua mengenai bauran promosi telah diperoleh sebagai berikut:

$\mathrm{R}$ (Interviewer) : "apakah ada cara lain untuk memasarkan selain iklan dengan media internet?"

M (Informan 1) : "saya sering kali mengajak pokja lain dalam tim PKK kelurahan bahkan kecamatan untuk datang ke kebun"

Peneliti mendapat pernyataan Ibu Restin tentang promosi berdasarkan kutipan wawancara berikut :

$\mathrm{R}$ (Interviewer) : " menurut ibu pemasaran yang efektif dan efisien menggunakan media apa atau dengan cara bagaimana"

A (Informan 2): "jika dimungkinkan, dapat ditampilkan di beberapa kegiatan pameran kota Kediri, meskipun tidak punya dana. Saya yakin bapak lurah dan bapak camat yang sudah beberapa kali berkunjung pasti berkenan untuk menjadi sponsornya"

Jawaban yang hampir sama dengan Ibu Budi juga dipaparkan oleh Ibu Tyas sebagai berikut ini :

$\mathrm{R}$ (Interviewer) : "ibu punya cara unik apa lagi untuk memasarkan sayuran hidroponik?

U (Informan 3) : "saya seneng memasak dan membawa hasil masakan saya ke tempat pertemuan pengajian atau rapat desa. Hal ini tak maksudkan, agar mereka tertaik untuk bertanya. Dengan label stiker yang dibagikan bu Budi, saya mengemasi hasil olahan hidroponik saya di tempat mika sesuai jenis masakannya dan kemudia diberikan striker"

\section{Noesis dan intentional analysis}

Tahap noesis dan intentional analysis ini harus dilakukan dalam satu tahap, yaitu melakukan pemaknaan yang lebih mendalam terhadap temuan data. Hasil pemaknaan yang didapatkan sebagai berikut ini :

Berdasarkan kutipan percakapan diatas dapat dimaknai bahwa informan ke-1, ke2 dan ke-3 mempunyai bahasa yang berebeda namun memiliki kandungan makna yang sama, yaitu bahwa masyarakat, pelanggan harus diberikan edukasi dan sosialisasi tentang hidroponik, mengajak konsumen untuk terlibat dalam kegiatan pemasaran sehingga hubungan yang baik antar pelaku usaha hidroponik, menjanjikan hubungan jangka panjang yang kuat dan harmonis antara pelaku usaha hidroponik dengan pelanggannya.

Noeisis dan intentional analysis dari ketiga informan adalah iklan menggunakan dokumentasi(foto, video, komentar persuasif) yang dimilikinya dan mereka memilih 
internet sebagai medianya. Interet menurut mereka lebih gampang, menarik, bisa ditambahkan jika ada dokumentasi yang terbaru dan pasti lebih banyak yang tahu. Ketiga informan juga menyatakan bahwa bentuk penjualan personal juga mereka terapkan dengan memperdayakan semua anggota mitra, hal ini dibuktikan dengan diberikannya label kemasan seperti yang disampaikan informan ketiga yaitu Ibu Tyas. Promosi penjualan dan penjualan secara langsung juga dilakukan, seperti yang dinyatakan oleh Ibu Budi, Ibu Restin dan Ibu Tyas, yaitu dengan memberi secara sepontanitas mereka menginformasikan tentang hidroponik mereka dimanapun mereka berada, saat belanja, saat mengikuti rapat, dan selalu habisnya hasil panen karena order yang diinformasikannya kepada ketua mitra hibah PKM UNP yaitu Ibu Budi. Untuk menciptakan pembelian dalam skala besar (biasanya untuk dijual kembali), ketiga informan menyatakan kerjasama atau kemitraan menjadi pilihan terbaik, karena secara keuangan lebih efektif (dana panen langsung bisa diterima keseluruhan) tidak sedikitsedikit.

\section{Eidetic reduction}

Untuk mendapatkan hasil yang lebih mendalam, peneliti melakukan analisis secara mendalam lagi sehingga dapat menemukan aktivitas-aktivitas dalam konsep pemasaran dan bauran promosi. Berkaitan dengan konsep pemasaran ditemukan bahwa pelaku pemasaran yang juga menjadi informan, melakukan konsep pemasaran ralasional dan sosial, ditunjukkan adanya perhatian pada peningkatan pengetahuan dan wawasan pada masyarakat atau mitra (mensejahterakan mitra secara non material), kerjasama saling menguntungkan, fokus pada kepuasan pelanggan, loyalitas pelanggan dan upaya menciptakan hubungan jangka panjang yang baik dengan semua pelanggannya. Adapun tentang bauran pemasaran, para palaku pemasaran yang juga informan menyatakan bahwa iklan, promosi penjualan, personal selling menjadi lebih efektif dan efisien ketika menggunakan media internet. Namun demikian penjualan langsung tetap dilakukan meskipun tidak sering, karena hanya beberapa kali dalam kegiatan pameran, bazar desa dan setiap ada pertemuan posyandu. Pemberian nama atau label pada kemasan sangat dirasakan manfaatnya oleh ketiga informan.

\section{Pembahasan}

Penerapan konsep pemasaran oleh pelaku usaha merupakan hal yang utama teruma pengusaha baru seperti halnya mitra hibah PKM peneliti ini. Keterbatasan faktor produksi yaitu lahan, orang dan uang harus dapat diantisipasi dengan strategi 
penerapan konsep pemasaran yang tepat. Perilaku konsumen yang semakin berkembang merupakan permasalahan serius dan harus terselesaikan. Kebutuhan dan keinginan konsumen harus diidentifikasi dengan baik, sehingga pemasar dapat menciptakan kepuasan pada pelanggannya (Kotler, 2009:6). Hubungan yang saling menguntungkan antara pemasar dan pelanggan harus diciptakan sehingga tercipta CRM dari pelanggan-pelanggan yang loyal. Seperti yang disampaikan oleh Ibu Tyas "Saya berharap penjualan dari pelanggan ini dapat mengajak konsumen-konsumen lainnya. Dan mungkin bisa kami tingkatkan dengan menjalin hubungan yang baik sehingga kami punya jaringan pemasaran yang luas "Memiliki produk yang termasuk dalam kategori convinience goods, pemasar harus mampu memasarkan dengan cara yang tepat memelalui bauran promosinya.

Di era digital ini maka media yang tepat untuk memasarkan hasil produk dari pengusaha yang mempunyai keterbatasan faktor-faktor produksi adalah media internet (Salim, 2010:183). Beberapa kelebihan internet diantara biaya rendah, mudah diaplikasikan, dekat dengan konsumen, sangat fleksibel untuk diperbaharui isinya, luas jangkauan pasarnya diakui oleh ketiga informan yaitu Ibu Budi, Ibu Restin dan Ibu Tyas. Hal ini disampaikan dengan sangat yakin oleh Ibu Restin "iklan dan promosi penjualan melalui internet. Beberapa kali saya coba melibatkan warga untuk menjadi agen penjualan dengan maksud awal ada yang fokus mengurus penjualan sayuruan, dan ternyata berhasil. Apalagi setelah tak kasih bonus karena menurut saya sudah melebihi target, lha sampek menolak pesanan lho!, sekarang tambah lebih rajin up load foto di status wa e, di facebooknya. Jadi menurutku promosi penjualan dan fee marketing sangat efektif". Bergabung dengan komunitas hidroponik Kediri sangat menguntungkan dari sisi keilmuan dan pemasaran, karena kami terbantu saat terjadi penumpukan hasil panen. Bagi kami kemitraan harus dilakukan untuk menjamin kontinyuitas produksi dan pemasaran. Pernyataan yang disampaikan oleh informan kedua yaitu Ibu Restin "Saling membantu dengan pelaku usaha lain juga menjadi bagian penting untuk menjamin kelangsungan hidup usaha kami. Karena usaha kami ini termasuk rawan mati suri, mengingat lahannya sangat minim dan titik tanam yang sangat sedikit dibawah seribu titik". Dari konsep pemasaran di era milenial ini, pernyataan ini menjadi implementasi dari konsep sosial, yaitu menciptakan kemitraan dan kerjasama dengan pelaku usaha dalam bidang usaha sejenis. 


\section{KESIMPULAN}

Dari temuan diatas dapat disimpulkan bahwa untuk dapat menyelesaikan keterbatasan faktor produksi yaitu lahan titik tanam yang minimum, anggota mitra yang belum semuanya memahami cara tanam hidroponik dan dana pemasaran yang terbatas adalah konsep pemasaran sosial dan relasional dengan mengelola CRM. Adapun media bauran promosi yang efektif untuk meningkatkan penjualan adalah menggunakan internet, baik untuk iklan, promosi penjualan,dan sangat membantu personal selling. Networking menjadi solusi bagi pelaku usaha skala kecil untuk terus bertahan dan berkembang di masa mendatang, karena dengan networking dapat menyelesaikan berbagai keterbatasan usaha, misalnya keterbatasan kerjasama dan lemahnya pemasaran. Hal ini senada yang disampaikan deputi pengembangan SDM Kementerian Koperasi dan UKM, Rulli Nuryanto pada workshop dan temu bisnis nasional UMKM yang digelar Direktorat Pengabdian Masyarakat Universitas Gadjah Mada (UGM) (Tribunnews.com, 30/10/2018).

\section{DAFTAR PUSTAKA}

Aliami, Fauji, dan Hakimah. 2018. "Dampak Pengembangan Pemasaran Digital Pada Start U p's (Studi Kasus Pada Wirausaha Baru)”. Jurnal Ekonika Vol. 3 No. 1

Hasanudin, dkk. 2011. Anxieties Desires: 90 Insights for Marketing to Youth, Women, Netizen in Indonesia. Jakarta:PT Gramedia Pustaka Utama.

Kamayanti, A. (2016). Metodologi Penelitian Kualitatif Akuntansi. (A. D. Mulawarman, Ed.). Jakarta: Ngapurancang.

Kotler, Philip dan Kevin Lane Keller. 2009. Manajemen Pemasaran. Jakarta: Indesk. PT. Macanan Jaya Cemerlang.

Malau, Harman. 2017. Manajemen Pemasaran Teori dan Aplikasi Pemasaran Era Tradisional sampai Era Modernisasi Global. Bandung: Alfabeta.

Moleong, L. J. (2017). Metode Penelitian Kualitatif (36th ed.). Bandung: PT Remaja Rosdakarya.

Salim, Joko. 2010. Online Entrepreneur. Jakarta:PT Elex Media Komputindo

Sugiyono. (2018). Metode Penelitian Kuantitatif, Kualitatif, Dan R\&D. Bandung: Alfabeta.

Wandanaya, Anita. 2012. "Pengaruh Pemasaran Online terhadap Keputusan Pembelian Produk". Journal CCIT (Creative Communication And Innovative Technology) Vol. 5 No.2

https://bisnisukm.com-kemitraan-harus-dilakukan-agar-ukm-maju

http://www.tribunnews.com/bisnis/2018/11/01/hadapi-era-revolusi-industri-40-polakemitraan-harus-dilakukan-agar-ukm-maju. 